\title{
Efficiency Evaluation Research of Missile Weapon System Based on the ADC - II Model
}

\author{
Wei Xia ${ }^{a}$, Xinxue Liu ${ }^{b}$, Shaofei Meng ${ }^{c}$ and Jinlong Fan ${ }^{d}$ \\ The Rocket Force University of Engineering, Shaanxi Xi'an 710025, China. \\ axiawei66@163.com, bliyax@sina.com, cshaofei_m@sina.com, d1340081949@qq.com
}

\begin{abstract}
Keywords: Missile weapon system; effectiveness evaluation; improved ADC model; fuzzy comprehensive evaluation
\end{abstract}

\begin{abstract}
In order to improve the whole effectiveness evaluation of the missile weapon system with stage character of flight course, put forwards the ADC system effectiveness evaluation method by stage, and improved the ADC model by using coefficient of operators' level of missile weapon system (K) and battlefield confrontation coefficient (Q). The effectiveness evaluation index system of missile weapon system is brought forward and a new improved effectiveness evaluation model (ADC- II) is given. The missile operational effectiveness is quantized by using experts mark, arrangement analysis, fuzzy comprehensive evaluation and weighted summation method. By example analysis, it is proved that this proposed method is of correctness and availability, which brings about the scientific decision-marking basis for the design and application of missile weapon system.
\end{abstract}

\section{Introduction}

Under the special conditions of battle circumstance, campaign assignment, deploying regiment, campaign flowing and capability testing of weapon accouter, Efficiency of weapon system accords with accomplishing the appointed campaign assignment (time, space, amount, and so on) by combining qualitative and quantitative analysis in time, space, percent, probability and amount, etc. It's required to evaluate the efficiency of missile system on optimizing combination, deploying assignment, judging intimidation extent of target object, designing control software and demonstrating requirement of new weapon. Nowadays, Evaluate the efficiency of weapon system not only can use the expert assessment method, statistic experimentation method, campaign simulation method, but also can use the quantitative scale method ${ }^{[1]}$, ADC method $^{[2 \sim 4]}$, analytic hierarchy process ${ }^{[5]}$ and cloud model ${ }^{[6]}$. Considering at the point of battlefield confrontation, this paper improved the traditional ADC model by using coefficient of operators' level of missile weapon system (K) and battlefield confrontation coefficient (Q) and break missile weapon system reliability (D) into product of initiative stage, middle stage and reentry stage. During the evaluating and analyzing course, the paper put forwards the dependability by stage and gave a new improved ADC method which accords with the characteristic of missile campaign better, evaluates efficiency more impersonal, and have more practical value.

\section{The Basic Principle and Improvement of ADC Model}

In traditional ADC model ${ }^{[7]}$, the efficiency is an anticipation measurement to satisfy a batch of task for the system. The function involves three variables: availability (A), Dependability (D) and capacity (C). Thus, the model is built as follows:

$$
E=A \cdot D \bullet C
$$

Where A is the capacity when system is in natural state at the beginning of the assignment, $\mathrm{D}$ is the capacity that working system can accomplish prescriptive function on condition that availability is given, $\mathrm{C}$ is the capacity measurement to accomplish prescriptive assignment for the system on condition that availability and dependability are given. Aiming at the stage characteristics of the aero missile weapon system, the improved ADC model is: 


\section{Evaluating Analysis of Missile Weapon System}

\subsection{Principle of Missile Weapon System.}

Missile weapon system is made up of firepower control subsystem and missile subsystem, where firepower control subsystem contains reconnaissance platform, control platform and send platform. After received the assignment, the missile system can obtain the target's position information by using the recon platform before launching, and then send to the control platform after editing by target disposal platform. At the last, the control platform flow the launch instruction to the send platform, and then complete the launch assignment. Operating principle is showed as Fig.1.

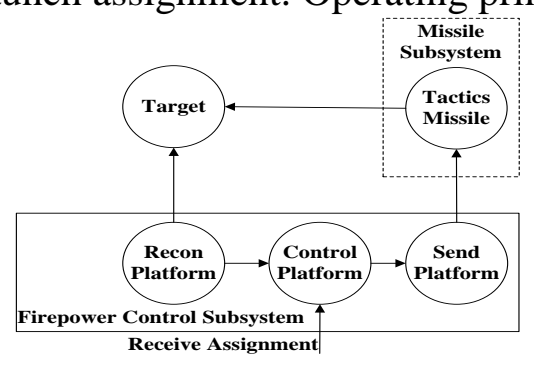

Fig.1 Principle of missile weapon system

\subsection{Effectiveness Evaluation Index of Missile Weapon System.}

By analyzing the constitution element and its function in assignment process of missile weapon system, the index system is structured and showed as Fig.2.

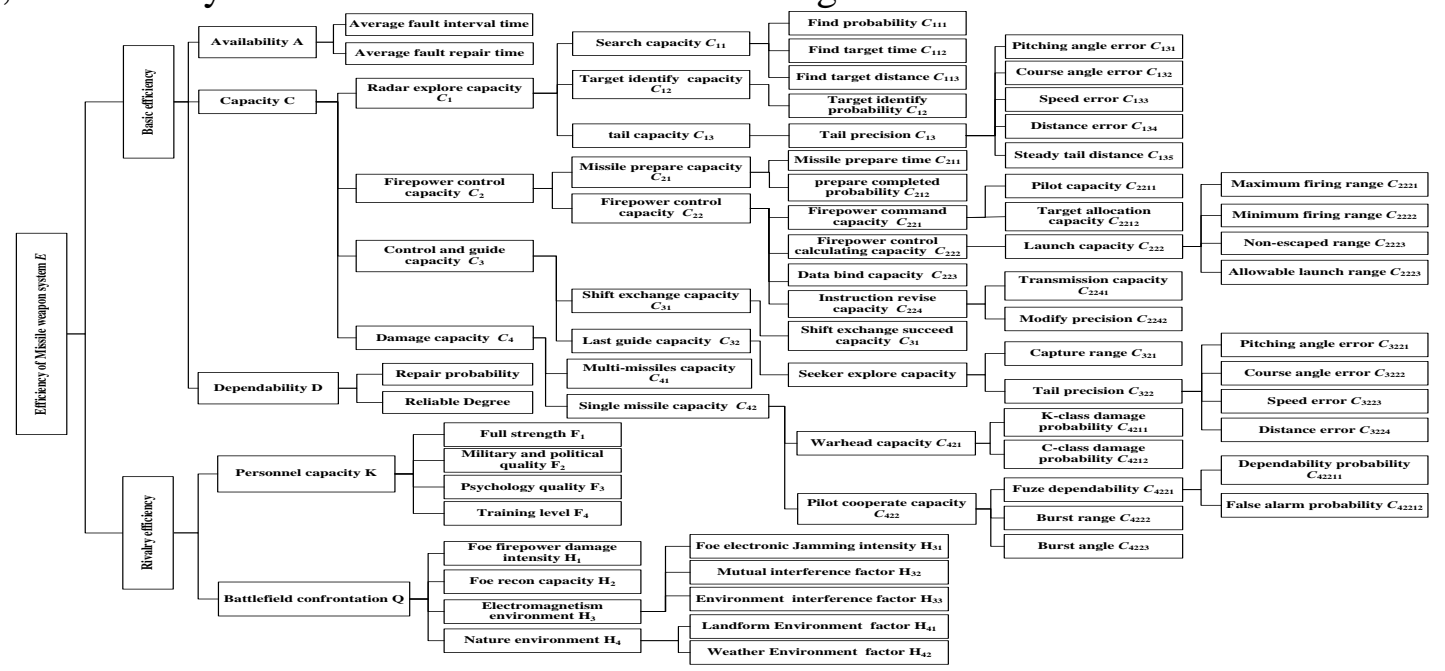

Fig.2 Effectiveness evaluation index of missile weapon system

Evaluating the effectiveness of missile weapon system in Fig.2 contains several steps as follows: availability evaluation before missile launching, namely the probability of each subsystem in regular state (A); dependability evaluation of the whole stage after missile launching and before hitting the target (D); connatural capacity evaluation of the missile system (C); confirm personnel capacity (K) and battlefield confrontation (Q). At the last, calculate the complex effectiveness value by using formula 2, namely evaluate the final damage capacity of the missile.

\section{Efficiency Evaluating of Missile Weapon System}

Known as Fig.1, the missile weapon system could be dimidiated into firepower control subsystem and missile subsystem, and each subsystem has two states (regular or fault), so missile system has 4 states shown as follow:

State 1: missile subsystem is regular, and firepower control subsystem is regular too;

State 2: missile subsystem is fault, but firepower control subsystem is regular;

State 3: missile subsystem is regular, but firepower control subsystem is fault;

State 4: missile subsystem is fault, and firepower control subsystem is fault too. 


\subsection{Confirm Availability of the System $A$.}

The availability of weapon system is the possibility of equipment used in battlefield on the basis of tasks ${ }^{[8]}$. Evaluating index mainly describe the states at the start of tasks for the working system. The availability is made up of all states probabilities at the beginning of tasks for the system ${ }^{[9]}$. Suppose this system works in regular state, and the mean time between failures (MTBF) and mean time to repair (MTTR) are satisfied the request of index, otherwise lost the tasks. So the availability of missile weapon system (A) can be expressed as follow:

$$
A=\left[a_{1}, a_{2}, a_{3}, a_{4}\right]
$$

Where $a_{1}, a_{2}, a_{3}, a_{4}$ are the probabilities of system in states $1 \sim 4$, i.e.

$$
A=\left[a_{M} a_{H},\left(1-a_{M}\right) a_{H}, a_{M}\left(1-a_{H}\right),\left(1-a_{M}\right)\left(1-a_{H}\right)\right]
$$

Where $a_{H}$ is the probability of regular firepower control subsystem; $a_{M}$ is the probability of regular missile subsystem.

As showed by Fig.1, firepower control subsystem is made up of recon platform, control platform and sending platform in series. So the probability of regular firepower control subsystem can be written as follows:

$$
A_{H}=a_{R} \cdot a_{C} \cdot a_{S}
$$

Where $a_{R} 、 a_{C}$ and $a_{S}$ respectively represent the availabilities of recon platform, control platform and sending platform.

In missile weapon system, a certain link may probably be made up of several kinds of different platform in parallel. For example, several sending platforms are composed in parallel to perform a sending task, if only one platform is in regular state, the system can finish the sending task. Take $m$ sending platforms as examples, the regular probability is:

$$
a_{S}=1-\left(1-a_{S 1}\right)\left(1-a_{S 2}\right) \cdots\left(1-a_{S m}\right)
$$

Where $a_{s m}$ is the regular probability of No. m sending platform.

For each basic weapon platform unit, the formula to calculate availability is showed as follow:

$$
a=\frac{M T B F}{M T B F+M T T R}
$$

Where MTBF is mean time between failures and MTTR is mean time to repair.

\subsection{Confirm Dependability of the System $D$.}

The Dependability evaluation means the stability of working system, mainly describes the states during performing tasks of the system. According to the character of launching missile, divided the flight course into 3 stages as follow:

Initiative stage: don't be intercepted, the affect factors are faults of engine and firepower control system.

Middle stage: be intercepted by foe middle-far distance weapon.

Reentry stage: be intercepted by foe short-ranged weapon (electronic jamming and firepower intercept).

4.2.1 Evaluate Dependability of Initiative Stage

Suppose the fault probability of missile engine is $p_{f}$ and firepower control system is $p_{g}$, the dependability of missile system in initiative stage is:

$$
D_{1}=\left[\begin{array}{llll}
d_{11}^{\prime} & d_{12}^{\prime} & d_{13}^{\prime} & d_{14}^{\prime} \\
d_{21}^{\prime} & d_{22}^{\prime} & d_{23}^{\prime} & d_{24}^{\prime} \\
d_{31}^{\prime} & d_{32}^{\prime} & d_{33}^{\prime} & d_{34}^{\prime} \\
d_{41}^{\prime} & d_{42}^{\prime} & d_{43}^{\prime} & d_{44}^{\prime}
\end{array}\right]=\left[\begin{array}{cccc}
\left(1-p_{f}\right)\left(1-p_{g}\right) & p_{f}\left(1-p_{g}\right) & \left(1-p_{f}\right) p_{g} & p_{f} p_{g} \\
0 & 1-p_{g} & 0 & p_{g} \\
0 & 0 & 1-p_{f} & p_{f} \\
0 & 0 & 0 & 1
\end{array}\right]
$$

Where $d_{i j}^{\prime}$ is the probability of missile which changed from state $i$ to $j$, for example, $d_{12}^{\prime}$ is the probability of missile that changed from state 1 to 2 . The same procedure may be easily adapted to obtain any other items in formulas(8,9 and 11).

\subsubsection{Evaluate Dependability of Middle Stage}

During this period, the effected factors of missile are mainly that the missile subsystem may be intercepted by foe middle-far distance weapon and firepower control subsystem may be attacked. 
Suppose the missile subsystem intercepted probability is $p_{t}$, and the firepower control subsystem attacked probability is $p_{h}$, thus the dependability of middle stage is showed as follow:

$$
D_{2}=\left[\begin{array}{cccc}
\left(1-p_{t}\right)\left(1-p_{h}\right) & p_{t}\left(1-p_{h}\right) & \left(1-p_{t}\right) p_{h} & p_{t} p_{h} \\
0 & 1-p_{h} & 0 & p_{t} \\
0 & 0 & 1-p_{t} & p_{h} \\
0 & 0 & 0 & 1
\end{array}\right]
$$

As the missile may be attacked by foe several kinds of interception weapon during the middle launching stage, the $k$ times intercepted probability of missile could be described as follow:

$$
p_{t}=1-\left(1-p_{t 1}\right)\left(1-p_{t 2}\right) \cdots\left(1-p_{t k}\right)
$$

Where $p_{t i}(i=1,2, \cdots k)$ is the No $i$ intercepted probability of the missile.

\subsubsection{Evaluate Dependability of Reentry Stage}

As the missile turns into the last self-guided link, neither the firepower control subsystem is regular nor fault, the probability changed to the next regular state is " 1 " while to the fault is " 0 ". Suppose the missile intercepted probability by short-range weapon is $p_{j}$, thus the dependability of last stage is:

$$
D_{3}=\left[\begin{array}{cccc}
1-p_{j} & p_{j} & 0 & 0 \\
0 & 1 & 0 & 0 \\
1-p_{j} & p_{j} & 0 & 0 \\
0 & 1 & 0 & 0
\end{array}\right]
$$

The dependability of missile is determined by the 3 launching courses: $D=D_{1} \cdot D_{2} \cdot D_{3}$ (12)

\subsection{Confirm Capacity of the System $C$.}

As a result of the missile used in assignment only has two patterns (regular or fault), it can consider the capacity of failure missile as zero. Accordingly the inherent capacity matrix of system can be described as follow:

$$
c=\left[c_{1}, c_{1}, 0,0\right]^{T}
$$

Where $c_{1}$ is the probability of fulfilling the assignment for missile weapon system in regular state, and the factor directly reflects the synthesis campaign capacity of missile.

Showed by Fig.3, the basic model of inherent capacity for the missile system is made up of radar explore capacity $C_{1}$, firepower control capacity $C_{2}$, control and guide capacity $C_{3}$ and damage capacity $C_{4}$, this paper adopts Analytic Hierarchy Process method and Fuzzy Comprehensive Evaluation method to deal with the capacity matrix $C$ :

Step1 according to Fig.2, confirm campaign capacity evaluation factor domain of discourse $U$

$U=\left\{u_{1}, u_{2}, u_{3}, u_{4}\right\}$, where $u_{1}=\left\{u_{11}, u_{12}, u_{13}\right\}, u_{2}=\left\{u_{21}, u_{22}\right\}, \quad u_{3}=\left\{u_{31}, u_{32}\right\}, u_{4}=\left\{u_{41}, u_{42}\right\}$.

Step2 confirm remark grade domain of discourse $V$

$V=\left\{v_{1}, v_{2}, v_{3}, v_{4}, v_{5}, v_{6}, v_{7}, v_{8}, v_{9}, v_{10}, v_{11}\right\}$

$=\{$ best, more better, better, good, less good, common, less bad, bad, worse, worst, none $\}$

$=\{1.0,0.9,0.8,0.7,0.6,0.5,0.4,0.3,0.2,0.1,0\}$.

Step3 construct factor judging fuzzy relation matrix $R$

$$
R=\left[\begin{array}{lll}
r_{11} & r_{12} & r_{13} \\
r_{21} & r_{22} & r_{23} \\
r_{31} & r_{32} & r_{33} \\
r_{41} & r_{42} & r_{43}
\end{array}\right]
$$

Where $r_{i j}$ is the subject relationship of factor $U_{i}$ in each layer evaluating factor set $U$ corresponding the grade $V_{j}$ in remark grade domain of discourse $V$, namely it's the single factor remark of the No $i$ for the remark object.

Step4 confirm remark factor weight vector

Use the AHP method to confirm each factor weight vector matrix $A=\left\{A_{1}, A_{2}, \cdots, A_{m}\right\}$ in evaluating factor domain of discourse $U$. Where $A$ is a fuzzy subset of the $U$, besides $\sum_{i=1}^{m} A_{i}=1, A_{i}>0$ is also 
satisfied.

Step5 fuzzy synthesis judge operation

Choose a fuzzy synthesis arithmetic operator“。”( $M(*,+)$ arithmetic operator $)$, synthesize $A$ and $R$ to obtain a fuzzy synthesis judge model: $B=A \circ R$, if $\sum_{i=1}^{m} B_{i} \neq 1$, carry out the normalization process.

Step6 calculate capacity $C$

When obtain the judge grade and corresponding points, calculate the grade of capacity by using the formula $\sum_{j=1}^{n} B_{j} \cdot V_{j}$.

\subsection{Confirm Coefficient of operators' level $K$.}

This part indicate the impact to the system caused by operators and commander, which are mainly decided by the full strength of missile troop, the operators' military and political quality, psychology quality in wartime and training level in peacetime, showed as Fig. 2. The coefficient of operators' level $K$ is given as follow:

$$
K=\sum_{i=1}^{4} \omega_{i} \cdot F_{i} \quad\left(F<1, \sum_{i=1}^{4} \omega_{i}=1\right)
$$

Where $\omega_{i}$ are weight vector decided by Expert Decision, $F_{i}$ is the extent of each index factors attained on campaign, commonly expressed as the form of probability.

\subsection{Confirm Battlefield Confrontation Coefficient $Q$.}

The impact to the efficiency caused by battlefield confrontation factor that are different from various environments, and various factor in the same environment are also different from each other. The expression of battlefield confrontation coefficient $Q$ is:

$$
Q=\sum_{i=1}^{4} \beta_{i} \cdot \sum_{j=1}^{n} \beta_{i j} H_{i j} \quad\left(H<1, \sum_{i=1}^{4} \beta_{i}=1, \sum_{j=1}^{n} \beta_{i j}=1\right)
$$

Where $H_{i j}$ are the values of factor in battlefield confrontation coefficient, $\beta_{i}$ and $\beta_{i j}$ are the corresponding weight vectors.

In conclusion, we can obtain the campaign efficiency of missile weapon system by taking the factors $K, Q, A, D$ and $C$ into the formula(2), showed as follow:

$$
E=\sum_{i=1}^{4} \omega_{i} F_{i} \cdot A \cdot\left(D_{1} \cdot D_{2} \cdot D_{3}\right) \cdot \sum_{j=1}^{4} B_{j} V_{j} \cdot\left(1-\sum_{i=1}^{4} \beta_{i} \cdot \sum_{j=1}^{n} \beta_{i j} H_{i j}\right)
$$

\section{Experiment and Results}

Suppose in local combat, our troops have a full strength, the solider aren't only familiar with the environment, but also have highly military, political and psychology quality. They perennially train in the campaign area and construct lots of self-contained sending strategic point, fortification, mobile way, headquarters and observation platform, etc. The foe troops not only have higher synthesis campaign capacity according to their plenty of campaign experience, but also are good at electronic war, recon exploring and associated damage.

\subsection{Compute Availability of the System $A$.}

Suppose a certain type of missile weapon system (contain missile and firepower control subsystems) attacked a target, the mean time between failures (MTBF) and mean time to repair (MTTR) are showed as Tab.1.

Tab 1 Mean time between failures and mean time to repair of missile weapon system

\begin{tabular}{ccccccc}
\hline Item & $\begin{array}{c}\text { Recon } \\
\text { Platform } \\
\text { NO.1 }\end{array}$ & $\begin{array}{c}\text { Recon } \\
\text { Platform } \\
\text { NO.2 }\end{array}$ & $\begin{array}{c}\text { Control } \\
\text { Platform } \\
\text { NO.1 }\end{array}$ & $\begin{array}{c}\text { Control } \\
\text { Platform } \\
\text { NO.2 }\end{array}$ & $\begin{array}{c}\text { Sending } \\
\text { Platform }\end{array}$ & Missile \\
\hline MTBF & 90 & 80 & 70 & 60 & 40 & 80 \\
MTTR & 4 & 3 & 1 & 1 & 2 & 2 \\
\hline
\end{tabular}


According to the Tab.1 and formula (7), the availability of missile subsystem and sending platform are separately showed as follows: $a_{M}=0.976, a_{S}=0.952$ 。

As the recon platform and control platform worked in parallel, their availability can be obtained by using formula (6) and (7):

$$
\begin{aligned}
& a_{R}=1-\left(1-\frac{90}{90+4}\right)\left(1-\frac{80}{80+3}\right)=0.998 ; \\
& a_{C}=1-\left(1-\frac{70}{70+1}\right)\left(1-\frac{60}{60+1}\right)=0.999 .
\end{aligned}
$$

According to formula (5), the probability of firepower control subsystem is: $a_{H}=a_{R} \bullet a_{C} \bullet a_{S}=0.949$.

According to formula (4) any more, the availability matrix is described as follow:

$$
A=\left[\begin{array}{lll}
0.926 & 0.0230 .050 & 0.001
\end{array}\right] \text {. }
$$

\subsection{Compute Dependability of the System $D$.}

Suppose the engine fault probability of missile is $p_{f}=0.04$, and the fault probability of firepower control system is $p_{g}=0.07$ in the initiative stage; the intercepted probability is $p_{t}=0.25$, and the attacked probability is $p_{h}=0.18$ in the middle stage; the missile intercepted probability by short-range weapon is $p_{j}=0.35$ in the reentry stage.

So according to formula (8 11), we can obtain the dependability matrix of these three stages showed as follow:

$$
D_{1}=\left[\begin{array}{cccc}
0.893 & 0.037 & 0.067 & 0.003 \\
0 & 0.930 & 0 & 0.07 \\
0 & 0 & 0.960 & 0.04 \\
0 & 0 & 0 & 1
\end{array}\right] \quad D_{2}=\left[\begin{array}{cccc}
0.615 & 0.205 & 0.135 & 0.045 \\
0 & 0.82 & 0 & 0.25 \\
0 & 0 & 0.75 & 0.18 \\
0 & 0 & 0 & 1
\end{array}\right] \quad D_{3}=\left[\begin{array}{cccc}
0.65 & 0.35 & 0 & 0 \\
0 & 1 & 0 & 0 \\
0.65 & 0.35 & 0 & 0 \\
0 & 1 & 0 & 0
\end{array}\right]
$$

Thus the dependability matrix of the system is:

$$
D=D_{1} \cdot D_{2} \cdot D_{3}=\left[\begin{array}{cccc}
0.468 & 0.530 & 0 & 0 \\
0 & 1.07 & 0 & 0 \\
0.468 & 0.465 & 0 & 0 \\
0 & 1 & 0 & 0
\end{array}\right]
$$

\subsection{Compute Capacity of the System $C$.}

On the basis of the Expert Decision, construct the estimation matrix by using the Analytic Hierarchy Process and test the coherence, such as Fig. 2 showed. All factors in the estimation matrix are educed from the statistical analysis of survey data given by the missile experts. Besides, they are satisfied the T.L.Saaty 1 9 scale method.

Tab 2 Index mark of system inherent ability

\begin{tabular}{lcccc}
\hline $\begin{array}{l}\text { System inherent } \\
\text { ability C }\end{array}$ & $\begin{array}{c}\text { Radar Explore } \\
\text { Capacity C1 }\end{array}$ & $\begin{array}{c}\text { Firepower } \\
\text { Control } \\
\text { Capacity C2 }\end{array}$ & $\begin{array}{c}\text { Control and } \\
\text { Guide } \\
\text { Capacity C3 }\end{array}$ & $\begin{array}{c}\text { Damage } \\
\text { capacity C4 }\end{array}$ \\
\hline $\begin{array}{l}\text { Radar Explore } \\
\text { Capacity C1 }\end{array}$ & 1 & $1 / 3$ & $1 / 2$ & $1 / 4$ \\
\hline $\begin{array}{l}\text { Firepower Control } \\
\text { CapacityC2 }\end{array}$ & 3 & 1 & $1 / 5$ & $1 / 3$ \\
\hline $\begin{array}{l}\text { Control and Guide } \\
\text { Capacity C3 }\end{array}$ & 2 & 5 & 1 & $1 / 3$ \\
\hline Damage capacity C4 & 4 & 3 & 3 & 1 \\
\hline
\end{tabular}

It's easy to obtain the results: $W=\left(\begin{array}{llll}0.0896 & 0.1392 & 0.2956 & 0.4756\end{array}\right), \quad \lambda_{\max }=4.4956$, C.I. $=0.0368$ and C.R. $=0.0401<0.1$, thus the estimation matrix satisfies the coherence index.

The each layer index weight vectors of capacity for the missile system are showed as Tab.3. 
Tab 3 Index weight vector of capacity matrix for the missile weapon system

\begin{tabular}{|c|c|c|c|c|c|c|c|c|c|c|c|c|c|c|c|c|c|c|c|c|}
\hline \multirow{2}{*}{ 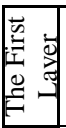 } & \multirow{2}{*}{$\begin{array}{l}\frac{1}{00} \\
\frac{.00}{2} \\
3\end{array}$} & \multirow{2}{*}{ 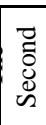 } & \multirow{2}{*}{$\begin{array}{l}\frac{1}{50} \\
\frac{.00}{00} \\
3\end{array}$} & \multirow{2}{*}{ 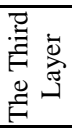 } & \multirow{2}{*}{$\begin{array}{l}\overrightarrow{0} \\
.000 \\
\overrightarrow{0} \\
3\end{array}$} & \multirow{2}{*}{ 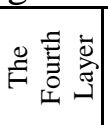 } & \multirow{2}{*}{$\begin{array}{l}\frac{7}{00} \\
\frac{00}{2} \\
3\end{array}$} & \multirow{2}{*}{ 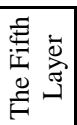 } & \multirow{2}{*}{$\begin{array}{l}\frac{7}{50} \\
.00 \\
3\end{array}$} & \multicolumn{11}{|c|}{ Remark grade domain of discourse } \\
\hline & & & & & & & & & & $\begin{array}{l}\vec{D} \\
\oplus \\
\oplus\end{array}$ & 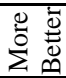 & 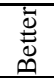 & $\begin{array}{l}\overline{8} \\
8 \\
0\end{array}$ & 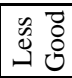 & 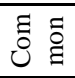 & 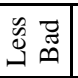 & ت्ञ్ & $\stackrel{n}{0}^{\circ} 0$ & $\begin{array}{l}\overrightarrow{5} \\
30 \\
3\end{array}$ & 艺 \\
\hline \multirow{9}{*}{ 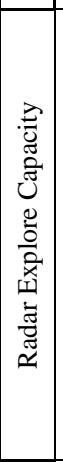 } & \multirow{9}{*}{$\begin{array}{l}\mathscr{2} \\
\stackrel{2}{0} \\
0 \\
0\end{array}$} & \multirow{3}{*}{$\vec{u}$} & \multirow{3}{*}{$\begin{array}{l}\text { ڤ్ } \\
\text { N̦ } \\
0\end{array}$} & $\mathrm{C}_{11}$ & 0.452 & & & & & 0.1 & 0.0 & 0.0 & 0.1 & 0.2 & 0.0 & 0.1 & 0.0 & 0.1 & 0.0 & 0.13 \\
\hline & & & & $\mathrm{C}_{11}$ & 0.316 & & & & & 0.0 & 0.0 & 0.1 & 0.1 & 0.1 & 0.0 & 0.0 & 0.1 & 0.2 & 0.0 & 0.02 \\
\hline & & & & $\mathrm{C}_{11}$ & 0.231 & & & & & 0.1 & 0.0 & 0.0 & 0.0 & 0.0 & 0.2 & 0.1 & 0.0 & 0.0 & 0.1 & 0.07 \\
\hline & & $\stackrel{\sim}{7}$ & $\begin{array}{c}0.237 \\
5\end{array}$ & $\mathrm{C}_{12}$ & 1 & & & & & $\begin{array}{c}0.0 \\
5\end{array}$ & $\begin{array}{c}0.1 \\
3\end{array}$ & $\begin{array}{c}0.2 \\
1\end{array}$ & $\begin{array}{c}0.0 \\
3\end{array}$ & $\begin{array}{c}0.0 \\
1\end{array}$ & $\begin{array}{c}0.0 \\
4\end{array}$ & $\begin{array}{c}0.0 \\
6\end{array}$ & $\begin{array}{c}0.1 \\
1\end{array}$ & $\begin{array}{c}0.0 \\
7\end{array}$ & $\begin{array}{c}0.0 \\
8\end{array}$ & 0.21 \\
\hline & & \multirow{5}{*}{$\mathcal{u}^{m}$} & \multirow{5}{*}{$\begin{array}{l}\stackrel{8}{0} \\
\text { ग } \\
0\end{array}$} & \multirow{5}{*}{$\mathrm{C}_{13}$} & \multirow{5}{*}{1} & $\mathrm{C}_{131}$ & 0.1 & & & 0.0 & 0.0 & 0.0 & 0.0 & 0.0 & 0.2 & 0.1 & 0.1 & 0.0 & 0.0 & 0.12 \\
\hline & & & & & & $\mathrm{C}_{132}$ & 0.2 & & & 0.3 & 0.0 & 0.0 & 0.0 & 0.0 & 0.1 & 0.1 & 0.0 & 0.0 & 0.0 & 0.23 \\
\hline & & & & & & $\mathrm{C}_{133}$ & 0.2 & & & 0.2 & 0.2 & 0.0 & 0.0 & 0.0 & 0.0 & 0.0 & 0.1 & 0.0 & 0.0 & 0.08 \\
\hline & & & & & & $\mathrm{C}_{134}$ & 0.1 & & & 0.1 & 0.0 & 0.0 & 0.0 & 0.0 & 0.1 & 0.0 & 0.1 & 0.1 & C.0 & 0.21 \\
\hline & & & & & & $\mathrm{C}_{135}$ & 0.2 & & & 0.0 & 0.0 & 0.0 & 0.0 & 0.0 & 0.1 & 0.2 & 0.1 & 0.0 & 0.1 & 0.07 \\
\hline \multirow{11}{*}{ 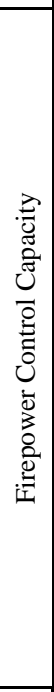 } & \multirow{11}{*}{ 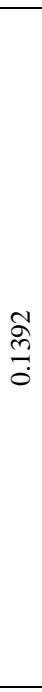 } & & 0.096 & $\mathrm{C}_{21}$ & 0.554 & & & & & 0.0 & 0.0 & 0.0 & 0.0 & 0.0 & 0.2 & 0.2 & 0.0 & 0.1 & 0.0 & 0.03 \\
\hline & & $\cup$ & 5 & $\mathrm{C}_{21}$ & 0.445 & & & & & 0.3 & 0.0 & 0.0 & 0.0 & 0.0 & 0.0 & 0.1 & 0.1 & 0.0 & 0.0 & 0.07 \\
\hline & & & & & 0.321 & $\mathrm{C}_{2211}$ & 0.4 & & & 0.0 & 0.0 & 0.0 & 0.0 & 0.1 & 0.0 & 0.0 & 0.0 & 0.0 & 0.1 & 0.25 \\
\hline & & & & $U^{N}$ & 1 & $\mathrm{C}_{2212}$ & 0.5 & & & 0.0 & 0.0 & 0.0 & 0.1 & 0.0 & 0.0 & 0.0 & 0.1 & 0.1 & 0.0 & 0.19 \\
\hline & & & & & & & & $\mathrm{C}_{22}$ & 0.3 & 0.2 & 0.1 & 0.0 & 0.0 & 0.0 & $\overrightarrow{0.0}$ & 0.1 & 0.0 & 0.0 & $\overrightarrow{0.0}$ & 0.23 \\
\hline & & & & & రิ & & & $\mathrm{C}_{22}$ & 0.1 & 0.1 & 0.0 & 5.1 & 0.0 & 0.0 & 0.0 & 0.0 & 0.1 & 0.0 & 0.0 & 0.10 \\
\hline & & & & $U^{N}$ & 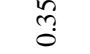 & $\mathrm{C}_{222}$ & 1 & $\mathrm{C}_{22}$ & 0.2 & $\frac{1}{0.0}$ & 0.0 & $\overline{0.0}$ & 0.0 & 0.0 & 0.0 & 0.1 & 0.0 & 0.2 & 0.0 & 0.29 \\
\hline & & & 学 & & & & & $\mathrm{C}_{22}$ & 0.3 & 0.1 & 0.1 & $\frac{1}{0.0}$ & 0.0 & 0.0 & 0.1 & 0.1 & 0.0 & $\frac{1}{0.0}$ & 0.3 & 0.05 \\
\hline & & U & ஷ̊. & $\mathcal{\exists}^{\cong}$ & $\begin{array}{c}0.212 \\
2\end{array}$ & & & & & $\begin{array}{c}0.0 \\
5\end{array}$ & $\begin{array}{c}0.0 \\
2\end{array}$ & $\begin{array}{c}0.0 \\
1\end{array}$ & $\begin{array}{c}0.0 \\
3\end{array}$ & $\begin{array}{c}0.0 \\
6\end{array}$ & $\begin{array}{c}0.0 \\
8\end{array}$ & $\begin{array}{c}0.0 \\
4\end{array}$ & $\begin{array}{c}0.0 \\
7\end{array}$ & $\begin{array}{c}0.0 \\
9\end{array}$ & $\begin{array}{c}0.1 \\
1\end{array}$ & 0.44 \\
\hline & & & & تี & 0.110 & $\mathrm{C}_{2241}$ & $\begin{array}{c}0.7 \\
68 \\
8\end{array}$ & & & $\begin{array}{c}0.1 \\
1\end{array}$ & $\begin{array}{c}0.0 \\
1\end{array}$ & $\begin{array}{c}0.2 \\
2\end{array}$ & $\begin{array}{c}0.1 \\
0\end{array}$ & $\begin{array}{c}0.0 \\
3\end{array}$ & $\begin{array}{c}0.0 \\
5\end{array}$ & $\begin{array}{c}0.0 \\
6\end{array}$ & $\begin{array}{c}0.0 \\
9\end{array}$ & $\begin{array}{c}0.1 \\
0\end{array}$ & $\begin{array}{c}0.1 \\
2\end{array}$ & 0.11 \\
\hline & & & & $U^{N}$ & 5 & $\mathrm{C}_{2242}$ & $\begin{array}{c}0.2 \\
31 \\
2 \\
\end{array}$ & & & $\begin{array}{c}0.1 \\
1\end{array}$ & $\begin{array}{c}0.0 \\
8\end{array}$ & $\begin{array}{c}0.1 \\
5\end{array}$ & $\begin{array}{c}0.0 \\
6\end{array}$ & $\begin{array}{c}0.0 \\
5\end{array}$ & $\begin{array}{c}0.1 \\
3\end{array}$ & $\begin{array}{c}0.0 \\
6\end{array}$ & $\begin{array}{c}0.1 \\
3\end{array}$ & $\begin{array}{c}0.0 \\
1\end{array}$ & $\begin{array}{c}0.0 \\
2\end{array}$ & 0.10 \\
\hline$\stackrel{\vec{Z}}{\vec{Z}}$ & & $\overrightarrow{\tilde{m}}$ & $\begin{array}{c}0.210 \\
3\end{array}$ & $\mathrm{C}_{31}$ & & & & & & $\begin{array}{c}0.0 \\
1\end{array}$ & $\begin{array}{c}0.0 \\
3\end{array}$ & $\begin{array}{c}0.0 \\
1\end{array}$ & $\begin{array}{c}0.0 \\
5\end{array}$ & $\begin{array}{c}0.0 \\
7\end{array}$ & $\begin{array}{c}0.0 \\
9\end{array}$ & $\begin{array}{c}0.1 \\
1\end{array}$ & $\begin{array}{c}0.0 \\
4\end{array}$ & $\begin{array}{c}0.2 \\
4\end{array}$ & $\begin{array}{c}0.0 \\
9\end{array}$ & 0.26 \\
\hline త্ত & & & & & & $\mathrm{C}_{321}$ & 0.2 & & & $\begin{array}{r}0.0 \\
\end{array}$ & 0.0 & 0.0 & 0.0 & 0.0 & 0.1 & 0.0 & 0.0 & 0.1 & 0.0 & 0.34 \\
\hline. & 㟔 & & & & & & & C3 & 0.1 & 0.0 & 0.0 & 0.0 & 0.1 & 0.1 & 0.0 & 0.0 & 0.0 & 0.0 & 0.1 & 0.23 \\
\hline 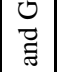 & Nִ & $\tilde{\tilde{\sigma}}$ & 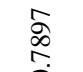 & $\mathrm{C}_{32}$ & 1 & & f & $\begin{array}{l}\text { C3 } \\
22 \\
\end{array}$ & $\begin{array}{r}0.2 \\
84 \\
\end{array}$ & $\begin{array}{c}0.0 \\
5 \\
\end{array}$ & $\begin{array}{c}0.0 \\
9 \\
\end{array}$ & $\begin{array}{c}0.0 \\
5\end{array}$ & $\begin{array}{c}0.1 \\
4 \\
\end{array}$ & $\begin{array}{c}0.0 \\
2 \\
\end{array}$ & $\begin{array}{c}0.0 \\
5 \\
\end{array}$ & $\begin{array}{c}0.1 \\
0 \\
\end{array}$ & $\begin{array}{c}0.1 \\
1 \\
\end{array}$ & $\begin{array}{c}0.1 \\
3 \\
\end{array}$ & $\begin{array}{c}0.0 \\
7\end{array}$ & 0.19 \\
\hline 号 & & & & & & $\mathrm{C}_{322}$ & 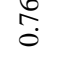 & $\begin{array}{l}\mathrm{C} 3 \\
22 \\
\end{array}$ & $\begin{array}{l}0.2 \\
66 \\
\end{array}$ & $\begin{array}{c}0.1 \\
0 \\
\end{array}$ & $\begin{array}{c}0.0 \\
3 \\
\end{array}$ & $\begin{array}{c}0.0 \\
5 \\
\end{array}$ & $\begin{array}{c}0.0 \\
2 \\
\end{array}$ & $\begin{array}{c}0.0 \\
8 \\
\end{array}$ & $\begin{array}{c}0.1 \\
2 \\
\end{array}$ & $\begin{array}{c}0.0 \\
6 \\
\end{array}$ & $\begin{array}{c}0.1 \\
6 \\
\end{array}$ & $\begin{array}{c}0.1 \\
3 \\
\end{array}$ & $\begin{array}{c}0.0 \\
6 \\
\end{array}$ & 0.19 \\
\hline نे & & & & & & & & $\begin{array}{l}\mathrm{C} 3 \\
27 \\
2\end{array}$ & $\begin{array}{r}0.4 \\
20 \\
\end{array}$ & 0.0 & 0.0 & 0.0 & $\begin{array}{r}0.0 \\
7\end{array}$ & $\begin{array}{c}0.0 \\
0.0\end{array}$ & 0.1 & $\begin{array}{c}0.2 \\
\end{array}$ & $\begin{array}{c}0.0 \\
0.0\end{array}$ & $\begin{array}{c}0.0 \\
2\end{array}$ & 0.1 & 0.07 \\
\hline & & $U^{F}$ & $\begin{array}{c}0.100 \\
2\end{array}$ & & & & & & & $\begin{array}{c}0.1 \\
5\end{array}$ & $\begin{array}{c}0.0 \\
5\end{array}$ & $\begin{array}{c}0.0 \\
9\end{array}$ & $\begin{array}{c}0.1 \\
2\end{array}$ & $\begin{array}{c}0.1 \\
7\end{array}$ & $\begin{array}{c}0.0 \\
2\end{array}$ & $\begin{array}{c}0.1 \\
4\end{array}$ & $\begin{array}{c}0.0 \\
7\end{array}$ & $\begin{array}{c}0.1 \\
1\end{array}$ & $\begin{array}{c}0.0 \\
6\end{array}$ & 0.11 \\
\hline & & & & & & $\mathrm{C}_{4211}$ & 0.4 & & & 0.0 & 0.0 & 0.1 & 0.1 & 0.1 & 0.0 & 0.0 & 0.1 & 0.1 & 0.0 & 0.02 \\
\hline & & & & $\overrightarrow{\mathcal{F}}$ & $\begin{array}{c}0.810 \\
3\end{array}$ & $\mathrm{C}_{4212}$ & $\begin{array}{c}0.5 \\
48 \\
9 \\
\end{array}$ & & & $\begin{array}{c}0.0 \\
4\end{array}$ & $\begin{array}{c}0.0 \\
6\end{array}$ & $\begin{array}{c}0.0 \\
5\end{array}$ & $\begin{array}{c}0.1 \\
7\end{array}$ & $\begin{array}{c}0.1 \\
1\end{array}$ & $\begin{array}{c}0.0 \\
4\end{array}$ & $\begin{array}{c}0.0 \\
2\end{array}$ & $\begin{array}{c}0.0 \\
9\end{array}$ & $\begin{array}{c}0.0 \\
7\end{array}$ & $\begin{array}{c}0.1 \\
6\end{array}$ & 0.19 \\
\hline 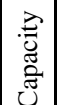 & h̊ & & & & & & $\stackrel{5}{9}$ & 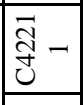 & 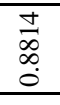 & $\begin{array}{c}0.0 \\
1\end{array}$ & $\begin{array}{c}0.0 \\
9\end{array}$ & $\begin{array}{c}0.0 \\
5\end{array}$ & $\begin{array}{c}0.1 \\
8\end{array}$ & $\begin{array}{c}0.0 \\
2\end{array}$ & $\begin{array}{c}0.0 \\
5\end{array}$ & $\begin{array}{c}0.1 \\
3\end{array}$ & $\begin{array}{c}0.1 \\
1\end{array}$ & $\begin{array}{c}0.1 \\
3\end{array}$ & $\begin{array}{c}0.0 \\
7\end{array}$ & 0.16 \\
\hline 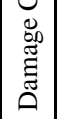 & f̊. & $\mathcal{f}^{f}$ & $\begin{array}{l}\infty \\
\stackrel{\infty}{\circ} \\
\infty \\
0\end{array}$ & & & U $^{7}$ & ֶֻ? & $\begin{array}{l}\text { Iี } \\
\text { Ũ }\end{array}$ & $\begin{array}{l}\infty \\
\infty \\
= \\
\\
0\end{array}$ & $\begin{array}{c}0.3 \\
5\end{array}$ & $\begin{array}{c}0.0 \\
2\end{array}$ & $\begin{array}{c}0.0 \\
5\end{array}$ & $\begin{array}{c}0.0 \\
4\end{array}$ & $\begin{array}{c}0.0 \\
1\end{array}$ & $\begin{array}{c}0.0 \\
8\end{array}$ & $\begin{array}{c}0.0 \\
8\end{array}$ & $\begin{array}{c}0.1 \\
4\end{array}$ & $\begin{array}{c}0.0 \\
8\end{array}$ & $\begin{array}{c}0.0 \\
9\end{array}$ & 0.06 \\
\hline & & & & $\mathcal{U}^{f}$ & 7 & ปี & 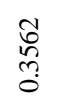 & & & $\begin{array}{c}0.0 \\
4\end{array}$ & $\begin{array}{c}0.0 \\
5\end{array}$ & $\begin{array}{c}0.0 \\
8\end{array}$ & $\begin{array}{c}0.0 \\
9\end{array}$ & $\begin{array}{c}0.1 \\
2\end{array}$ & $\begin{array}{c}0.0 \\
4\end{array}$ & $\begin{array}{c}0.0 \\
2\end{array}$ & $\begin{array}{c}0.0 \\
9\end{array}$ & $\begin{array}{c}0.0 \\
7\end{array}$ & $\begin{array}{c}0.1 \\
7\end{array}$ & 0.23 \\
\hline & & & & & & $\mathcal{J ี ~}^{\dddot{7}}$ & 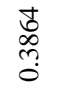 & & & $\begin{array}{c}0.0 \\
5\end{array}$ & $\begin{array}{c}0.0 \\
2\end{array}$ & $\begin{array}{c}0.0 \\
1\end{array}$ & $\begin{array}{c}0.0 \\
3\end{array}$ & $\begin{array}{c}0.0 \\
6\end{array}$ & $\begin{array}{c}0.1 \\
8\end{array}$ & $\begin{array}{c}0.0 \\
4\end{array}$ & $\begin{array}{c}0.0 \\
7\end{array}$ & $\begin{array}{c}0.1 \\
5\end{array}$ & $\begin{array}{c}0.0 \\
1\end{array}$ & 0.38 \\
\hline
\end{tabular}

Compute the capacity value by using fuzzy relationship synthesized theory, and the value of No.3 layer for the search, capacity is: 


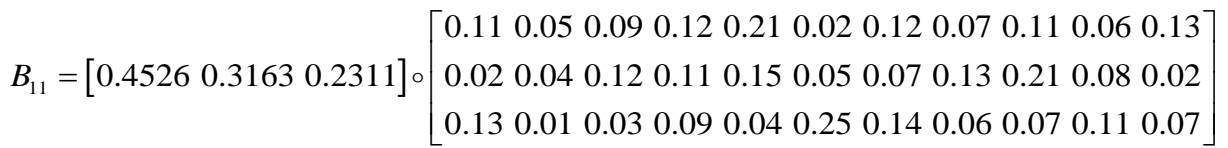

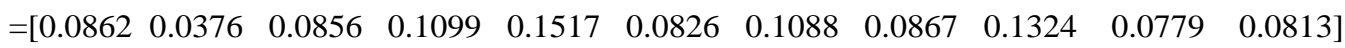

The same procedure may be easily to obtain the value of No.3 layer for the tail capacity:

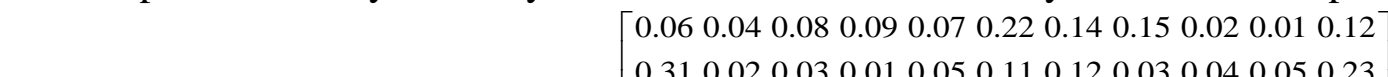

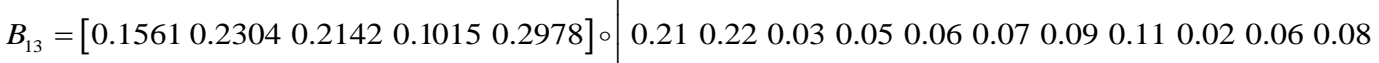

$$
\begin{aligned}
& \begin{array}{lllllllllll}
0.11 & 0.03 & 0.05 & 0.01 & 0.08 & 0.12 & 0.06 & 0.14 & 0.13 & 0.06 & 0.21
\end{array}
\end{aligned}
$$

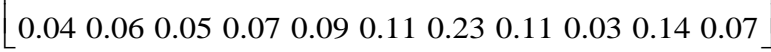

$$
\begin{aligned}
& =\left[\begin{array}{lllllllllll}
0.1488 & 0.0789 & 0.0458 & 0.0489 & 0.0702 & 0.1196 & 0.1434 & 0.1009 & 0.0388 & 0.0737 & 0.1310
\end{array}\right] \\
& B_{1}=\left[\begin{array}{lll}
0.3256 & 0.2375 & 0.4369
\end{array}\right] \circ\left[\begin{array}{l}
B_{11} \\
B_{12} \\
B_{13}
\end{array}\right]
\end{aligned}
$$

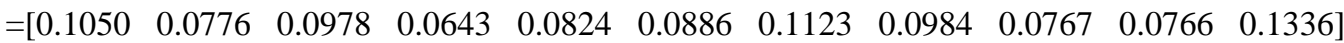

The same procedure, we can obtain these factors as follow:

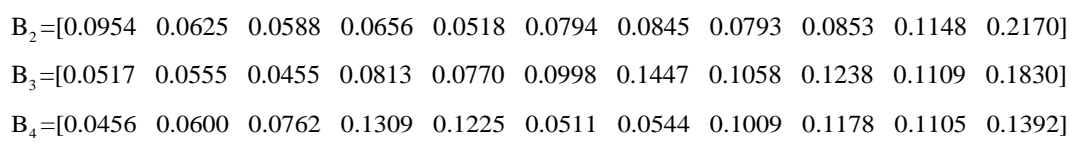

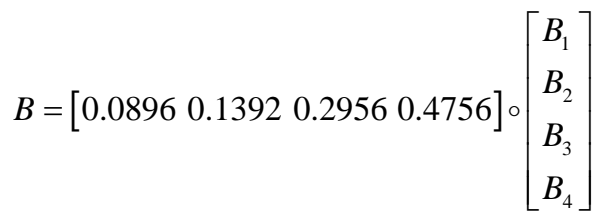

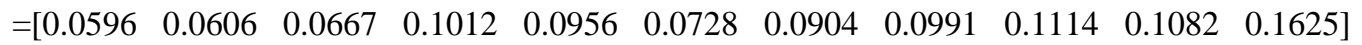

Therefore, the capacity value of the missile weapon system in regular state is:

$$
C=B \cdot V^{T}
$$$$
=0.0596 * 1+0.0606 * 0.9+0.0667 * 0.8+0.1012 * 0.7+0.0956 * 0.6+0.0728 * 0.5+0.0904 * 0.4+0.0
$$

\section{$991 * 0.3+0.1114 * 0.2+0.1082 * 0.1+0.1625 * 0=0.4311$}

And according to the formula (13), the capacity matrix is showed as:

$$
C=\left[\begin{array}{llll}
C_{1} & c_{1} & 0 & 0
\end{array}\right]^{T}=\left[\begin{array}{llll}
0.4311 & 0.4311 & 0 & 0
\end{array}\right]^{T} .
$$

\subsection{Compute $K$ and $Q$.}

Considering at the practice and the design performance of the missile weapon system, we can

\begin{tabular}{|c|c|c|c|c|c|}
\hline Items & No.1 Index & Weight & No.2 Index & Weight & Parameters \\
\hline \multirow{7}{*}{$\begin{array}{c}\text { Battlefield } \\
\text { Confrontation } \\
\text { Q }\end{array}$} & Foe Firepower & 0.46 & & & 0.35 \\
\hline & Foe Recon & 0.25 & & & 0.28 \\
\hline & \multirow{3}{*}{ Electromagnetism } & \multirow[t]{3}{*}{0.18} & Foe Electronic & 0.5 & 0.16 \\
\hline & & & Mutual Interference & 0.2 & 0.21 \\
\hline & & & Envīironment & 0.3 & 0.25 \\
\hline & \multirow[t]{2}{*}{ _ Nature } & \multirow[t]{2}{*}{0.11} & Landform & 0.7 & 0.23 \\
\hline & & & Weather & 0.3 & 0.16 \\
\hline \multirow{4}{*}{$\begin{array}{l}\text { Operators’ } \\
\text { Level K }\end{array}$} & Full Strength & 0.1 & & & 0.75 \\
\hline & Military and & 0.3 & & & 0.80 \\
\hline & Psychology Quality & 0.2 & & & 0.85 \\
\hline & Training Level & 0.4 & & & 0.90 \\
\hline
\end{tabular}
obtain the weight vectors and correlative parameters of the coefficient of operators' level $K$ and battlefield confrontation coefficient $Q$ showed as Tab.4.

Tab 4 Weight vectors and correlative parameters of coefficient of operators' level and battlefield confrontation 
According to formula(14 and 15), we can get the results:

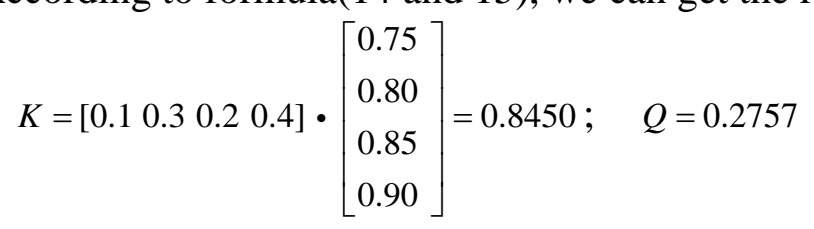

\subsection{Compute Complex Efficiency of Missile Weapon System $E$.}

According to formula(2), we can get the results:

$$
\begin{aligned}
& E=K \cdot A \cdot\left(D_{1} \cdot D_{2} \cdot D_{3}\right) \cdot C \cdot(1-Q) \\
& =0.8450 \cdot(1-0.8330) \cdot\left[\begin{array}{llll}
0.926 & 0.023 & 0.050 & 0.001
\end{array}\right] \cdot\left[\begin{array}{cccc}
0.468 & 0.530 & 0 & 0 \\
0 & 1.07 & 0 & 0 \\
0.468 & 0.465 & 0 & 0 \\
0 & 1 & 0 & 0
\end{array}\right] \cdot\left[\begin{array}{c}
0.4311 \\
0.4311 \\
0 \\
0
\end{array}\right]=0.2629
\end{aligned}
$$

In conclusion, comparing at the impact of nature environment, the synthesis efficiency of missile weapon system influenced by the foe intercepted firepower, electronic jamming, recon exploring and battlefield electromagnetism environment are more greatly. At the same time, the system efficiency is also influenced by the coefficient of operators' level and battlefield confrontation seriously. Therefore, the troop should not only keep a certain intensity of combat readiness, full strength and military training, but also pay attention to the operators' political quality education and psychology quality training.

\section{Conclusions}

Considering at the stage character of the missile flight course, this paper break the dependability in traditional ADC method into product of different stages. Besides, the results with accession to the coefficient of operators' level $\mathrm{K}$ and battlefield confrontation coefficient $\mathrm{Q}$ accord with the working rule of campaign missile better. At the same time, the missile inherent capacity matrix is quantized analyzed by Experts Decision, Analytic Hierarchy Process, Fuzzy Comprehensive Evaluation and weighted summation method, it is also of benefit to realize the impact intensity caused by different factors to the missile system. The proposed method not only offers a reference for the design and application of missile weapon system, but also would be suitable for the other systems that with staged working course.

\section{References}

[1] Niu Kun, Pang Zhi-bing. A comprehensive method for effectiveness evaluation of weapon system[J]. Information Command Control System \& Simulation Technology, 2005, 27(1):50-53.

[2] Chen Jian, Teng Ke-nan, Yang Chun-zhou. Effectiveness evaluation model of antisatellite equipment SoS based on ADC method[J].Ship Electronic Engineering, 2014,3(34):116-119.

[3] Wang Jun, Zhao Jie, Shao Lei, etc. System effectiveness evaluation model of ground to air missile based on ADC method[J]. Modern Defence Technology, 2015, 6(43):13-20.

[4] Qi Shan-ming, Li Lei. Operational effective -ness evaluation of command information system based on the improved ADC model[J]. Ship Electronic Engineering, 2012, 5(32):30- 33.

[5] Jin Xin, Xu Jun, Zeng Jie. The research of system effectiveness evaluation model[J] Command Information System and Technology,2011,2(11):36-40.

[6] Xu Zheng-jie, Zhang You-peng, Su Hong-sheng. Application of risk assessment on fuzzy comprehensive evaluation method based on the cloud model[J]. Journal of Safety and Environment, 2014, 14(2):69-72.

[7] Dong You-xin. Research on the method of effectiveness evaluation[M].Beijin: National Defence Industry Press, 2009:27-29.

[8] Zhao Ji-hua, Wu Yong. Assessment of effectiveness for an equipment based on fuzzy arrangement analysis method[J]. Journal of Safety and Environment, 2010,31(11):53- 55. 
[9] Zhou Yan, Cheng Lang-zhong, Li Wei-min. Assessment of operational effectiveness for the bullet-shell system based on the BP network[J]. System Engineering and Electronics, 2005, 27(1):84-86.

[10]Li De-yi, Du Yi. Artificial intelligence with uncertainty[M]. Beijin: National Defence Industry Press, 2005. 